\title{
Annals of Forest Research: ten years of international publication
}

\author{
S. Popescu, M. Teodosiu
}

Popescu S., Teodosiu M., 2018. Annals of Forest Research: ten years of international publication. Ann. For. Res. 61(1): 3-4.

Authors. Sorin Popescu - Texas A\&M University, 221D Centeq Building, TAMU 2123, College Station, TX 77843, USA; Marius Teodosiu (marius.teodosiu@gmail.com) - "Marin Drăcea“"National Research-Development Institute in Forestry, Station Câmpulung Moldovenesc, 725100 Câmpulung Moldovenesc, Suceava, Romania.

Manuscript received July 10, 2018; revised July 12, 2018; accepted July 14, 2018; online first July 15, 2018.

Apart of the great things of any anniversary - this time, a decade of Annals of Forest Research as an international scientific publication - this is also a good opportunity to reflect about the past.

In a brief overview on the journal's history, Marin Drăcea could be remembered as father of the first forest research institute in Romania and also as initiator, under the first name, of „Annals of the Forest Research and Experimentation Institute" (1934). The journal was published every year, except for the period following the Second World War (19471950) and after the fall of the communist regime (1989-2000) (Popescu et al. 2014). Such a good initiative is now supported by already famous quotes on publishing, highlighting its importance for science: "A scientific experiment (...) is not completed until the results are published.” or „The goal of scientific research is publication." (Day 1998).

A rebirthing of the journal took place in
2008 , by opening to the international audience. This change was related to the IUFRO conference "Breeding and Genetic Resources of Five-Needle Pines" (Working Party 2.02.15, September 19-23, 2006, Văliug, Romania) (Blada et al. 2008), followed by other partnerships - "Forum Carpathicum 2017" (September 28-29, Bucharest, Romania) (Egan et al. 2017, Niculae et al. 2017) and 50 years of FORMEC (September 25-29, 2017 - Brașov, Romania) (Borz et al. 2017).

In 2011, the journal was indexed by ISI Thomson Reuters, and three years later got the first impact factor $\left(\mathrm{IF}_{2013}=0.444\right)$. Now, on its 10 th aniversary in international publishing, the journal has been ranked the 36th out of 66 international journals in Forestry $\left(\mathrm{IF}_{2017}=1.320\right.$, InCites Journal Citation Reports, Clarivate Analytics).

Overall, in the span of 10 years, Annals of Forest Research has published 240 articles, contributions of 740 authors from 45 coun- 
tries. From today's perspective, these can also be found in the last editorial (Popescu et al. 2014): ,... the journal has made significant progress in multiple aspects, for instance the increase of manuscripts number and topics, the diversity of the author's country of origin and the quality of the articles".

The success of the journal would not be possible without the submissions of the authors, the generous support coming from the reviewers and from all the people who have linked their name to Annals of Forest Research over the past 10 years. We send all of them our deepest gratitude for contributing to its development and we are looking forward to the next decade.

\section{References}

Blada, I., King, J., Sniezko, R. 2008. Proceedings of the IUFRO Working Party 2.02.15 "Breeding and Genetic Resources of Five-Needle Pines" Conference held from September 19 to 23, 2006, Văliug, Romania. Annals of Forest Research 51(1): 3-4.

Borz, S., Acuna, M., Heinimann, H., Palander, T., Spinelli, R. 2017. "Innovating the competitive edge: from research to impact in the forest value chain": half-century of FORMEC. Annals of Forest Research 60(2): 199201. DOI:10.15287/afr.2017.914

Day, R.,A. 1998. How to write and publish a scientific paper. 5th edition, Oryx Press, Phoenix, Arizona, USA

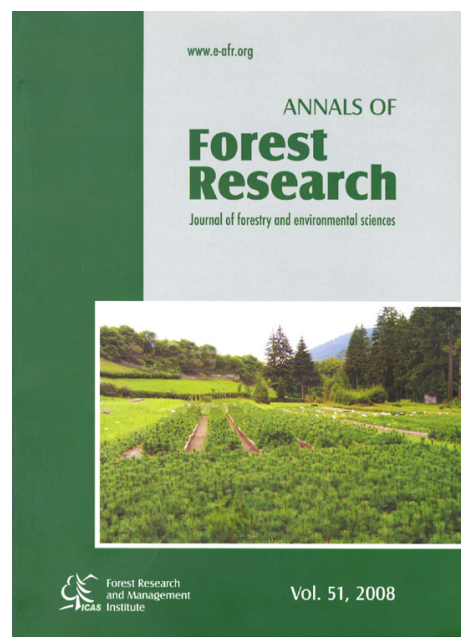

Cover of the first international issue

Egan, A., Keeton, W., Danks, C., Zia, A., Soloviy, I. 2017. Forest carbon projects in the Ukrainian Carpathians: an assessment of potential community impacts and benefits. Annals of Forest Research 60(1): 3-17. DOI:10.15287/afr.2016.718

Niculae, M., Avram, S., Vânău, G., Pătroescu, M. 2017. Effectiveness of Natura 2000 network in Romanian Alpine Biogeographical Region: an assessment based on forest landscape connectivity. Annals of Forest Research 60(1): 19-32. DOI:10.15287/afr.2016.793

Popescu, S., Biriș, I., Teodosiu, M., Bouriaud, O., Olenici, N., Mohor, D. 2014. Annals of Forest Research: 80 years from first publishing. Annals of Forest Research 57 (1): 3-4. DOI: 10.15287/afr.2014.183 